\title{
PENDIDIKAN HUMANIS KH AHMAD DAHLAN, KI HAJAR DEWANTARA DAN PAULO FREIRE
}

\author{
Supala $^{1}$, Dita Handayani ${ }^{2}$, Anwar Rifai ${ }^{3}$ \\ Fakultas Ilmu Keislaman, Universitas Muhammadiyah Bandung ${ }^{1}$ \\ supala@gmail.com¹,dita_handayani@gmail.com², anwarrifai.m.ag@gmail.com³
}

\begin{abstract}
The background of this issue, there are cases of violence mostly by educators is still emerged, must be a serious concern concern, which is shows the low understanding of educators about the concept of humanist education, as exemplified by KH Ahmad Dahlan, Ki Hajar Dewantara or Paulo Friere as a famous figure of educators. The research is aimed to understand the humanist educational thought of a religious patterned (KH Ahmad Dahlan), nationalist (Ki Hajar Dewantara) and socialistic (Paulo Friere) style of humanist education. The method used in this research is a library research with a qualitative approach, by doing descriptive analysis and interpreting the data obtained. The results of this research shows that KH Ahmad Dahlan, Ki Hajar Dewantara and Paulo Freire have similarities in viewing humanist education, although they have a slightly differences in the use of terms and methods of field practical application.
\end{abstract}

Keywords: Humanist, Character, Independent, Education, Progressive

\begin{abstract}
Abstrak
Latar belakang, masih bermunculan kasus tindak kekerasan oleh pendidik di sekolah merupakan keprihatinan, yang menunjukan rendahnya pemahaman pendidik tentang konsep pendidikan humanis, seperti yang dicontohkan tokoh KH Ahmad Dahlan, Ki Hajar Dewantara atau pun Paulo Friere. Tujuan penelitian untuk memahami pemikiran pendidikan humanis bercorak religius ( $\mathrm{KH}$ Ahmad Dahlan), nasionalis (Ki Hajar Dewantara) dan corak sosialistis (Paulo Friere), supaya memberi pencerahan dan bersikap bijak. Metode yang digunakan adalah pendekatan library reaseach dengan pendekatan kualitatif yaitu dengan malakukan analisis deskriftif dan melakukan interpretasi atas datadata yang diperoleh. Hasil dari studi (penelitian) ini menunjukan bahwa KH Ahmad Dahlan, Ki Hajar Dewantara dan Paulo Freire memiliki kesamaan dalam memandang pendidikan yang bersifat humanis, meskipun sedikit berbeda dalam penggunaan istilah dan metode penerapannya secara praksis di lapangan.
\end{abstract}

Katakunci: Humanis, Karakter, Merdeka, Pendidikan, Progresip 


\section{A. PENDAhULUAN}

Dunia pendidikan memiliki nilai investasi yang penting, yang nantinya akan berguna untuk masa depan. Hal ini terjadi karena munculnya anggapan yang memandang hidup dengan orientasi serba materi, sehingga memandang dunia pendidikan pun dari aspek materi saja. Maka ini bisa menimbulkan sikap hedonism, mencintai materi, bahkan sikap arogan dan menghalalkan segala cara. Pendidikan dipandang sebagai profesi biasa yang bernilai ekonomi semata, dan hanya menjadi pekerjaan yang sifatnya rutinitas. Maka tanggungjawab mendidik menjadi kabur, yang terjadi hanya sekedar transfer knowledge. Bila pandangan demikian yang membudaya, maka tidak heran bila kemudian muncul tindakan-tindakan yang paradok dengan nilainilai dan tujuan pendidikan yang manusiawi (bijaksana). Guru yang semestinya bertindak sebagai pendidik justru bisa berlaku egois, dan bertindak tidak manusiawi meskipun atas nama kedisiplinan.

Kasus tindakan kekerasan dalam dunia pendidikan masih sering terjadi. Sepanjang tahun 2019, KPAI menerima 153 aduan kekerasan fisik terhadap siswa ${ }^{i}$ Per 30 Desember 2019, KPAI menyatakan kasus kekerasan di sekolah mayoritas dilakukan guru. KPAI menyayangkan masih ditemukan tindakan guru yang menerapkan hukuman fisik dalam penegakan disiplin sekolah. "Padahal perbuatan kekerasan akan berdampak buruk bagi tubuh kembang anak. selain itu tidak membuat anak menghentikan perilakunya,' demikian menurut Komisioner KPAI Bidang Pendidikan, Retno Listyanti $(30 / 12-2019){ }^{\text {ii }}$

Berdasarkan jenjang pendidikannya, tindakan kekerasan fisik bisa dilihat table di bawah ini adalah:

Tabel 1.

Kekerasan Fisik/Perundungan dan Jenjang Pendidikan

\begin{tabular}{|c|l|c|}
\hline No & \multicolumn{1}{|c|}{ Jenjang Pendidikan } & Prosentase (\%) \\
\hline 1 & SD/MI & $39 \%$ \\
\hline 2 & SMP/Sederajat & $22 \%$ \\
\hline 3 & SMA/SMK/MA & $39 \%$ \\
\hline & Total & $100 \%$ \\
\hline
\end{tabular}

Memperhatikan table di atas menunjukan dari sebaran kasus tindakan kekerasan di tiap jenajang pendidikan di tanah air sepanjang tahun 2019, angka prosentase dibawah $50 \%$; tetapi ini kasus yang muncul kepermukaan. Bisa jadi ini seperti fenomena gunung es, yang tampak di bagian atas nya saja.

Pendidikan yang humanis, manusiawi sesuai dengan alur pribadi kemanusiaan pernah diwacanakan di abad modern, sejak dimunculkan para filosof pendidikan pada abad ke-18, seperti John Locke dan JJ Rousse, hingga pendidikan multi kecerdasan. Di tanah air, pendidikan yang humanis masih berlangsung sampai tahun 1990-an. Bahkan di era reformasi pun dalam prakteknya pendidikan yang humanis tidak mudah diaplikasikan sesederhana dalam konsep. Hal ini dikarenakan pendidikan humanis ditentukan dengan kualitas sumber daya manusia guru (pengajar) dalam proses pembelajaran tersebut, selain soal kebijakan. 
Alih-alih menjadi pendidik yang berkualitas SDM, justru kita masih menemukan banyak kasus yang memprihatinkan dalam tindakan kekerasan yang dilakukan oleh kalangan pendidik di lingkungan sekolahnya. Data mutakhir setahun belakangan menunjukan hal tersebut, yang diterima KPAI.iii seperti dilihat di table di bawah ini.

Tabel 2.

Pelaku Kekerasan dan dan Prosentase

\begin{tabular}{|c|l|c|}
\hline No & \multicolumn{1}{|c|}{ Jenjang Pendidikan } & Prosentase (\%) \\
\hline $\mathbf{1}$ & Kepala Sekolah \& Guru & $44 \%$ \\
\hline 2 & Siswa terhadap guru & $13 \%$ \\
\hline 3 & Orangtua terhadap siswa & $13 \%$ \\
\hline 4 & Siswa terhadap siswa & $30 \%$ \\
\hline & Total & $100 \%$ \\
\hline
\end{tabular}

Begitu pun dengan table berikutnya, yang menunjukan pelaku tindakan kekerasan tersebut, yang mayoritas dilakukan oleh pendidik (Kepala sekolah dan guru) yang semestinya menjalankan prinsip pendidikan yang manusiawi (humanis), justru yang terjadi sebaliknya. 44\% pelaku kekerasan dilakukan oleh kepala sekolah/gurunya sendiri. Menarik dicermati pula, pelaku siswa terhadap guru (pendidiknya) sebanyak 13\%. Kalau dijumlahkan pendidik dan peserta didik, sebagai pelaku kekerasan adalah 57\%; baru sisanya pelaku siswa bertindak kekerasan terhadap sesama siswa (30\%), dan perilaku orangtua terhadap siswa (13\%). Ini memberi isyarat dalam proses KBM (kegiatan belajar mengajar) seolah terjadi pola "guru kencing berdiri murid kencing berlari". Pendidik memberikan contoh kekerasan terhadap peserta didik, sebaliknya siswa pun meniru gurunya melakukan kekerasan. Bila disatukan yang melibatkan guru dengan siswa adalah 40\%,13\%,30\%, jumlahnya menjadi $83 \%$ kejadian tindakan kekerasan itu melibatkan guru dan siswa dengan kejadian tampaknya dominan terjadi di lingkungan sekolah. Suatu angka kejadian yang cukup besar, $83 \%$ terjadi kekerasan di lingkungan dunia pendidikan.

Kasus kekerasan di sekolah pun kejadiannya sampai menimbulkan korban jiwa. Dari 171 kasus yang menimpa anak, diantaranya 2 siswa meninggal yaitu di SMA TI kota Palembang, meninggal saat masa pengenalan lingkungan sekolah (MPLS). Seorang siswa SMPS di kota Manado juga meninggal setelah dihukum lari keliling lapangan sekolah, karena siswa tersebat terlambat datang. Meskipun angka korban jiwa kecil, tetapi ini sudah cukup menjadi indicator betapa di lingkungan pendidikan pun, pendidik masih dominan (banyak) yang menjadi pelaku kekerasan (44\%) baik sebagai kepala sekolah atau sebagai guru. Ini menunjukan mereka tidak memahami dan mengamalkan prinsip pendidikan yang manusiawi (humanis).

Padahal prinsip konsep pendidikan di negeri kita sudah jelas sekali. Bahkan undang-undang No.82/2015 tentang Permendikbud tentang Seorang pendidik tidak boleh bertindak kekerasan fisik kepada anak didik/siswa. Tujuan pendidikan nasional yang ada, serta prinsip pendidikan yang manusiawi (humanis) setidaknya telah ditampilkan oleh dua (2) figure tokoh pendidikan humanis baik yang bercorak nasional, seperti Ki Hajar Dewantara atau pun pendidikan humanis yang bercorak 
religious(keagamaan) seperti KH Ahmad Dahlan. Keduanya sudah memasuki masa 1 abad dalam menggelorakan prinsip pendidikan humanis. Selain itu kemajuan modern pun memunculkan pemikiran pendidikan humanis yang bercorak sosialistis seperti yang diungkapkan filosof pendidikan, Paulo Friere.

Rupanya prinsip pemikiran pendidikan dan keteladanan tokoh pemikir pendidikan sekelas KH Ahmad Dahlan dan Ki Hajar Dewantara, termasuk filosof Paulo Freire, yang konsentrasi pada persoalan pendidikan humanis sepertinya tidak dikenal oleh kalangan pendidik. Tampaknya menggali (kembali) pemikiran pendidikan humanis, baik bercorak nasionalis (Ki Hajar Dewantara), bercorak religious (KH Ahmad Dahlan), dan bercorak sosialistis (Paulo Freire) menjadi penting untuk dilakukan di lingkungan para pendidik. Dimana ketiga tokoh ini memiliki kesamaan pokok pikiran tentang pendidikan yang harus membangun nilai-nilai manusiawi (humanis), itulah pendidikan yang merdeka. Meskipun ada beberapa perbedaan kecil yang ada terutama terkait metode.

Karena pertimbangan kondisi tersebut di atas, maka penting upaya melakukan kajian atas pemikiran pendidikan dari ketiga tokoh tersebut, diharapkan bisa menjadi jalan pembuka nalar bijaksana di kalangan praktisi pendidikan.

Pentingnya mengapresiasi pendidikan humanis yang dicontohkan para praktisi yang mumpuni dan diakui dalam konteks pendidikan nasional di negeri kita, menjadi persoalan yang layak dipertimbangkan kembali untuk menjadi kajian. Itulah yang melatarbelakangi penelitian ini untuk ditampilkan dalam tulisan yang diberi judul," Pendidikan Humanis KH Ahmad Dahlan, Ki Hajar Dewantara dan Paulo Freire."

Pilihan untuk membandingkan pendidikan humanis tokoh pendidikan nasional KH Ahmad Dahlan, Ki Hajar Dewantara dan pemikir pendidikan dari luar, Paulo Freire karena ketiga tokoh ini secara subtsansial memiliki kesamaan dalam memandang pendidikan yang humanis. Meskipun ada variasi-variasi istilah yang digunakan berbeda, atau sedikit pendekatan yang berbeda.

\section{B. METODE}

Dalam pengumpulan data pada penelitian ini, penulis menggunakan pendekatan kualitatif dengan mengumpulkan sumber-sumber data pustaka baik dalam bentuk bukubuku, artikel jurnal, dalam hal ini bentuk cetak dan online. Yang dimaksud pendekatan kualitatif diartikan sebagai penelitian yang menghasilkan data deskriptif dalam hal ini bersifat tertulis. ${ }^{\text {iv }}$ Penelitian atas data-data yang bersumber dari khasanah kepustakaan. ${ }^{\mathrm{v}}$ Dalam hal ini bersumber dari buku-buku dan jurnal. Kemudian dilakukan analisis

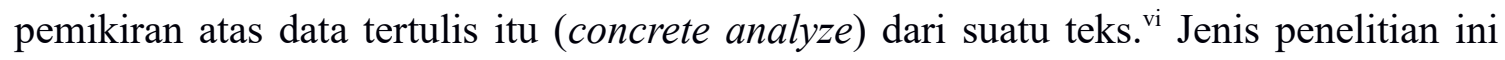
dengan menggunakan pendekatan deskriptif analisis yaitu pencarian berupa fakta, hasil dan ide pemikiran seseorang melalui cara mencari, menganalisis, membuat interpretasi serta melakukan generalisasi terhadap hasil penelitian yang dilakukan. ${ }^{\text {vii }}$ Dalam hal ini penulis kemudian mengolah data-data tersebut dengan melakukan proses analisis kritis terhadap perilaku dan pemikiran tokoh tersebut. 


\section{HASIL DAN PEMBAHASAN}

\section{Hasil}

Pendidikan (bahasa Indonesia) merupakan terjemahan dari kata education, yang merupakan turunan dari bahasa Latin educare. Boleh jadi secara etimologis, kata pendidikan berasal dari du akata kerja yang berbeda, yaitu dari kata educare dan educere. Kata educare dalam bahasa latin memiliki konotasi melatih atau menjinakkan (seperti dalam konteks manusia melatih hewan-hewan yang liar menjadi semakin jinak sehingga bisa diternakkan), menyuburkan (membuat tanah itu lebih menghasilkan banyak buah berlimpah karena tanahnya yang digarap dan diolah). Jadi, pendidikan merupakan sebuah proses yang membantu menumbuhkan, mengembangkan, mendewasakan, membuat yang tidak tertata atau liar menjadi smekain tertata, semacam proses penciptaan sebuah kultur dan tata keteraturan dalam diri maupun dalam diri orang lain. Selain, merupakan semacam domestifikasi, pendidikan juga berarti proses pengembangan berbagai macam potensi yang ada dala, diri manusia, seperti kemampuan akademis, relasional, baka-bakat, talenta, kemmapuan fisik, atau daya-daya seni. ${ }^{\text {viii }}$

Term humanis, bermakna kata benda, 1. Orang yang mendambakan dan memperjuangkan terwujudnya pergaulan hidup yang lebih baik, berdasarkan asas perikemanusiaan; pengabdi kepentingan sesame umat manusia; 2. Penganut paham yang menganggap manusia sebagai objek terpenting; 3. Penganut humanisme. Humanisme adalah sebuah pemikiran filsafat yang mengedepankan nilai dan kedudukan manusia serta menjadikannya sebagai kriteria dalam segala hal. Istilah Humanisme berasal dari bahasa Latin, humanus, dari kata homo artinya manusia yang bermakna manusiawi atau sesuai kodrat manusia. Istilah ini semula digunakan pada public secara profesional berkaitan dengan literatur klasik abad pertengahan berhubungan dengan keterampilan menulis surat dan berbicara. Dari sini berkembang maknanya secara lebih komprehensip. ${ }^{\text {ix }}$

Pendekatan teoritis yang digunakan dalam penelitian ini adalah teori humanisme yang dalam pandangan Antonio Gramci yang memandang pendidikan humanistik bernilai demokratis. ${ }^{\mathrm{x}}$ Juga pandangan tokoh pemikir muslim Iran, Ali Syariati yang memandang aliran filsafat humanisme bermuara pada tujuan pokok keselamatan dan kesempuranaan manusia. ${ }^{x i}$ Lebih lanjut Antonio Gramci berpandangan, pendidikan yang manusiawi diperlukan untuk pendidikan kepada siswa supaya tumbuh sense of moral judgment dan tanggungjawab sosialnya menjadi makin besar. ${ }^{\text {xii }}$

\section{a. Praksis dan Pemikiran Pendidikan KH Ahmad Dahlan}

KH Ahmad Dahlan merupakan pelopor praksis pendidikan modern di Indonesia. Konsep pendidikannya yang bersifat holistic (integrative), mengkombinasikan pendidikan modern-rasional ala barat dengan spirit religious. Dalam pemikirannya ajaran Islam harus dipahami secara modern (berkamajuan) dan rasional, hal demikian memiliki kesamaan apa yang dilakukan dalam metode pendidikan barat. 
Untuk mengkaji pemikiran KH Ahmad Dahlan, diperlukan pendekatan studi sejarah (historical study) atas perjalanan hidupnya. Untuk mengungkap pemikirannya, perlu mengkaji riwayat-riwayat yang disampaikan murid-murid dan generasi penerusnya, selain pula menganalisis atas artefak hasil buah amal perjuangannya. Terlebih pula karena minimnya karya tulis tokoh ini. Bukan tidak bisa menulis, tetapi KH Ahmad Dahlan sengaja menekankan pada aspek aksi daripada konsep (teori). Beliau itu lebih sebagai man of action (manusia) amal daripada sebagai ahli teori.

KH Ahmad Dahlan lebih memfokuskan amal gerakannya, ini didasari prinsipnya dalam mengajar murid-muridnya yang memfokuskan pada "ayat-ayat sosial", yang kemudian dikumpulkan oleh salahstau muridnya RH Hadjid. Dalam menafsir ayat-ayat KH Ahmad Dahlan tidak terjebak pada penafsiran yang elaborative, tetapi memilih untuk mendorong aplikasi nyata dari semangat ayat tersebut. ${ }^{\text {xiii }}$ Pantaslah bila kemudian gerakannya melahirkan Lembaga amal sosial kemanusiaan seperti madrasah, sekolah, panti asuhan, poliklinik, dan Lembaga PKO (Penolong Kesengsaraan Oemoen). ${ }^{\text {xiv }}$ Ajaran Islam dalam pandangan KH Ahmad Dahlan harus diamalkan (praksis), sebagai mukmin tanpa mempraktikan apa yang diperintahkan oleh Tuhan dan Nabi Muhammad, bukanlah seorang mukmin tetapi munafik (hipokrit), suatu status yang harus dihindari oleh semua muslim. ${ }^{\mathrm{x}}$

Menarik dicermati pemikiran KH Ahmad Dahlan dalam menggerakan sosial keagamaan, justru dengan berfokus awalnya pada persoalan pendidikan. Jauh sebelum Muhammadiyah yang dikenal sebagai organisasi umat Islam yang modern dan semakin kian berkembang secara progressif; KH Ahmad Dahlan justru berkonsentrasi pada pemberdayaan manusia atau persoalan pendidikan secara luas. KH Ahmad Dahlan berangkat dari gerakan mendobrak pada persoalan filsafat pendidikan, yaitu mengubah paradigma berpikir masyarakat yang sebelumnya bersifat feodalistik, mistis, tidak rasional, tradisional kepada berpikir rasional modern. Meskipun beliau sendiri tidak mengalami pendidikan modern (sekolah Belanda), tetapi bersentuhan pemikiran modernnya dengan kalangan rasional modern seperti Syekh Muhammad Abduh. ${ }^{\text {xvi }}$

Corak pemikirannya maju dan terbuka (inklusif), berbeda dengan kiai pada umumnya di zamannya. KH Ahmad Dahlan sangat terbuka terhadap semua faham atau aliran pemikiran, dalam kerangka menimba ilmu dan mengembangkan ilmu pengetahuan. Karakteristik seperti ini menunjukan model manusia modern-yang sesungguhnya ini pula karakteristik muslim yang paripurna, yang dicontohkan nabi saw dan generasi awal umat Islam. Beliau bersifat terbuka dan fleksibel dalam hal menimba ilmu dan mengembangkan ilmu pengetahuan, progressif, tetapi lentur dalam menyampaikan pelajarannya.

Dalam menyampaikan pengajaran, metode pendidikan yang disampaikannya bersifat praktis dan disesuaikan dengan kondisi murid (pembelajar). Digambarkan bagaimana KH Ahmad Dahlan dalam mengajarkan pelajaran agama kepada murid-muridnya, melibatkan murid-muridnya aktip 
dalam belajar. Misalnya dalam mempelajari konsep agama KHA Dahlan mengilustraskan melaksanakan agama itu dengan analogi menggunakan alat music biola, dimana bila tidak menguasai Teknik memainkannya maka akan melahirkan suara yang falsa tau bising tidak nyaman didengar, jauh dari bisa dinikmati secara indah. Begitulah agama bila dilakukan oleh orang yang tidak memahaminya dengan tata cara yang tepat. ${ }^{\text {xvii }}$

Selain itu KH Ahmad Dahlan dalam pendidikan humanis itu ditunjukan ketika proses pembelajaran, dimana posisi guru-murid digambarkan sebagai mitra sejajar, partner belajar bagi muridnya. Pendekatan ini membuat terjalin hubungan kedekatan yang nyaman dan membuat belajar menjadi menggembirakan bagi murid, sebuah teknik pendidikan yang tabu dilakukan saat itu. Tradisi saat itu guru atau kiai berposisi sebagai guru murid dalam hubungan atasan dan bawahan, sehingga murid menjadi segan atau takut untuk melakukan tanya jawab dengan sang guru. Inilah pendidikan humanis yang "demokratis" yang diajarkan kepada murid-muridnya.

Dalam hal metode pendidikan, KH Ahmad Dahlan melakukan gebrakan dengan memperkenalkan metode mengajar murid bertanya lebih dahulu kepada guru. Suatu teknik yang baik bagi mengundang pemahaman murid terhadap pelajaran yang disampaikan guru. ${ }^{\text {xiii }}$ Suatu ciri khas yang berbeda dengan kiai di zaman tersebut.

Dalam menafsirkan ayat al-Qur'an pun ia bercorak progresif-seperti menafsir Q.S. Ali Imran ayat 104-konsep umat terbaik yang menyeru kepada al-khair (kebaikan) dan mencegah kepada kemunkaran disajikan dengan pemahaman yang modern. Ayat tersebut dimaknai menuntut untuk menggunakan pendekatan teologi modern supaya memberikan solusi bagi persoalan kemanusiaan dan memuat nilai-nilai transendental pada pendidikan humanis. Dengan ayat ini KH Ahmad Dahlan memberikan pendidikan kepada para pelajar dengan cara yang bijaksana. Diantaranya KH Ahmad Dahlan memberikan pembelajaran pada kelompok pengajian tafsir yang dikenal dengan Fathul Ashar Miftahu Sa'adah kepada para pelajar usia 25 tahunan supaya mereka tidak jatuh kepada tindak kenakalan dan kemaksiatan, tetapi beramal saleh untuk membangun Muhammadiyah. Ini strategi yang unik yang digunakan KH Ahmad Dahlan untuk mendidik anak-anak, dengan memberikan inisiatip mengikutsertakan mereka untuk belajar dengan bertamasya (piknik) dan mendatangkan pelatih untuk beberapa orang yang menyukai seni musik. ${ }^{\text {xix }}$ Ini merupakan strategi dakwah yang unik, secara kultural memberikan solusi bagi anak-anak muda yang bermasalah. Pendidikan model seperti ini memberikan ruang kepada pelajar untuk mendapatkan solusi. Dan dialog humanis antara guru dan murid dalam menyelesaikan masalah.

Selanjutnya pendidikan humanis yang dilakukan $\mathrm{KH}$ Ahmad Dahlan ditunjukan dengan memberikan pelayanan pendidikan tidak saja kepada muridmurid yang berasal ari Kauman dari kalangan santri, tetapi pula memberikan layanan belajar bagi murid-muridnya yang dari kalangan umum (bukan santri) 
berpendidikan Kweekschool Belanda yang ingin belajar agama. Juga melayani pendidikan bagi kalangan remaja puteri (kaum perempuan) dan mendidik muridmurid perempuannya, serta mengirim mereka melanjutkan pendidikan di sekolah-sekolah Belanda.

KH Ahmad Dahlan memberikan pendidikan humanis dengan memberi teladan dimana guru aktip menemui muridnya. Ini pun suatu di luar kebiasaan yang pada umumnya justru sebaliknya. Bila diibaratkan seperti "sumur mencari timba." Gerakan KH Ahmad Dahlan ini merupakan proses mendesakralisasikan kiai, yang semula dikultuskan sangat berlebihan. Dikritiknya dengan sikap demikian, sehingga kiai atau guru mengaji justru menghormati murid. Metode demikian menjadikan pendidikan bersifat humanis karena menjadikan murid tidak lagi takut menghadapi gurunya, tetapi guru menjadi mitra (partner) dalam

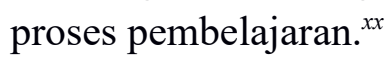

KH Ahmad Dahlan memberikan pendidikan secara arif kepada muridmuridnya, sekaligus mengajak muridnya untuk membuka pola piker rasional dan humanis. Dengan mengajarkan tafsir surat Al-Ma'un (teologi Al-Ma'un) yang berulang-ulang sampai ada muridnya yanga merasa bosan dan aneh. Kemudian ia menjelaskan bahwa belajar mengaji al-Qur'an tidak berhenti dipembacaan teks, sekedar dirapalkan seperti membaca mantera atau sekedar dihafalkan. $\mathrm{KH}$ Ahmad Dahlan menuntun murid-muridnya supaya memahami dan mengaplikasikan pelajaran ayat-ayat al-Qur'an tersebut dalam realitas sosial, sehingga ajaran al-Qur'an itu bisa dirasakan keberadaannya. Ini merupakan cermin pendidikan yang humanis yang membawa misi kerasulan. Dimana muridmuridnya disentuh pikiran dan jiwanya untuk peka terhadap lingkungan sosial kemanusiaan. Bersama-sama muridnya mereka mencari dan membawa anakanak yatim dan fakir miskin untuk disantuni dan diberikan pendidikan. ${ }^{\text {xxi }}$ Dari aksi tersebut kemudian berkembang selanjutnya menjadi amal usaha sosial Panti Asuhan Yatim, dan rintisan Penolong Kesengsaraan Oemoem (PKO) serta klinik sebagai cikal bakal rumah sakit Muhammadiyah.

\section{b. Pemikiran Pendidikan Ki Hajar Dewantara}

Ki Hajar Dewantara adalah bapak Pendidikan Nasional. Lahir pada 2 Mei 1889 dengan nama Raden Mas Soewardi Soeryaningrat, berasal dari keluargaa Kadipaten Pakualaman Yogyakarta. ${ }^{\text {xii }}$ Merupakan pelopor pendidikan untuk masyarakat pribumi di Indonesia ketika masih dalam masa penjajahan colonial Belanda. Soewardi beruntung menemouh ksemepatan Bersama anak-anak bangsa Eropa di Sekolah Dasar Belanda, ELS (Europeesche Lagere School). ${ }^{\text {xiii }}$ Ia melanjutkan studi di STOVIA (Sekolah Dokter Pribumi) di Batavia, tidak tamat karena menderita sakit. Kemudian ia berkarir menjadi wartawan di beberap suratkabar seperti Sediotomo, Midden Java, De Expres, Oetoesan Hindia, Kaoem Moeda, Tjahaja Timoer dan Poesara. Gaya penulisannya tajam mencerminkan semangat anti colonial. Ia dikenal karena kritikannya "Andaikan Aku seorang Belanda" yang mengkritik perayaan kemerdekaan bangsa Belanda 
di negeri kita. Karena kritikannya itu ditangkap dan dibuang (diasingkan) ke Bangka. Bahkan kemudian ia dibuang ke negeri Belanda. Justru disanalah ia kemudian menimba ilmu dan meraih ijazah pendidikan (Europeesche Akte), sehingga dengan itu membantu bisa mendirikan Lembaga pendidikan di Indonesia. ${ }^{\text {xxiv }}$

Pandangan Ki Hajar Dewantara tentang pendidikan pada dasarnya berpijak pada filsafat pendidikan progresivisme. Menurut H.A.R. Tilaar, Ki Hajar Dewantara sudah mengenal pemikiran pendidikan barat dari John Dewey, Maria Montessori, Kerchrnsteiner, dan Jan Lighthart, yang mengadopsi pendidikan secara teoritis dan praksis. ${ }^{\mathrm{xxv}}$ Pandangannya tentang pendidikan yang berhubungan erat dengan kebudyaan.

Dari sudut pandang sosio antropologis, manusia memiliki ciri khas yang berbeda dengan makhluk lainnya yaitu berakal. Dengan akalnya itu manusia itu berbudaya, sementara makhluk lainnya tidak berbudaya. Dan salahsatu cara untuk menjadikan manusia lebih manusiawi adalah dengan mengembangkan kebudayaanya. Uniknya manusia memiliki keragaman budaya dalam masyarakat, sehingga berlaku pepatah "lain ladang lain balakang lain lubuk lain ikannya." Manusia akan benar-benar menjadi manusia, kalau hidupnya dengan budayanya sendiri. Dan manusia seutuhnya ketika manusia itu sendiri dilengkapi dengan budaya masyarakatnya. ${ }^{\text {xxi }}$

Dalam hal hubungan manusia dengan lingkungan yang menaunginya, maka manusia berada dalam tiga keadaan, yaitu sebagai dirinya sendiri, keluarga, dan masyarakat. Ini yang dikenal dengan istilah tripusat dalam pandangan Ki Hajar Dewantara. Revitalisasi Tripusat Pendidikan Ki Hajar Dewantara ini dikenal konsep pendidikannya yang mengintegrasikan pendidikan dengan kebudayaan. Integrasi pendidikan dan kebudayaan oleh Ki Hajar Dewantara telah ditekankan sedari dini mungkin sejak TK, dengan fokus pada panca indera sebagai modal uatama untuk meningkatkan kecerdasan dan budi pekertinya. ${ }^{\text {xvvii }}$ Konsep tripusat pendidikan $\mathrm{Ki}$ Hajar, yaitu pertama pendidikan dalam keluarga, kedua penddiikan alam perguruan (sekolah), dan tiga, pendidikan dalam alam pemuda (Masyarakat). ${ }^{\text {xxvii }}$

$\mathrm{Ki}$ Hajar termasuk tipe penganut pendidikan progressive, yaitu dengan ciricirinya: pertama, pendidikan bermuasal dari anak-anak, yang mana memiliki kebutuhan dan keinginan dalam hidupnya. Kedua, peserta didik adalah bersifat sebagai subyek aktif bukan pasif. Anak bukanlah sekedar makhluk pasif yang menanti guru. ${ }^{\text {xix }}$ Adapun tentang pendidik, berfungsi hanya sebagai penasehat, pembimbing dan pemandu daripada sebagai pemegang kekuasaan dilingkungan. Dalam pendidkan progressive, anak merupakan titik fokus sebagai subyek ataupun obyek dalam pendidikan. sedangkan dalam hal aktivitas pendidikan itu sendiri dalam pendidikan progressive adalah memfokuskan pada problem solving. Pendidikan itu menekankan pada pemecahan masalah. Dengan demikian maka harus pula didukung dengan atmosfir dalam pendidikan harus bersifat kooperatif dan demokratis. ${ }^{\mathrm{xxx}}$ 
Dalam pengertian Ki Hajar Dewantara, mendidik bukan sekedar untuk meningkatkan intelektual. Mendidik merupakan pula upaya untuk menumbuhkan budipekerti (karakter batin), pikiran (intellect) dan tubuh jasmani sekaligus secara bersamaan. Ia pun menekankan pentingnya pendidikan yang menyatu dengan kebudayaan; yaitu pendidikan yang mengupayakan tumbuhnya budipekerti sebaik-baiknya antara pikiran, perasaan dan kemauan yang ketiganya harus dicerdaskan. Pendidikan pada aspek intelektual sudah sangat jelas, sampai sekarang menjadi proritas utama dalam sistem pendidikan nasional. Tetapi yang sering diabaikan adalah pendidikan yang mengembangkan aspek perasaan dan kemauan. Padahal pribadi yang baik tidak datang sendiri tetapi diperlukan waktu dan proses untuk dibentuk. ${ }^{\text {xxxi }}$

Pendidikan budipekerti yang berbasis pada budaya bangsa yang dikembangkan dan dicontohkan oleh guru atau pamong, dengan konsep "tringa" yaitu ngerti (mengetahui), ngroso (menginsyafi), nglakoni (melakukan) yang dipadukan dengan metode pembelajaran dengan system among, menjadi sistem pembelajaran yang diterapkan Taman Siswa, dengan semboyannya Tut Wuri Handayani. Dengan konsep itu Ki Hajar Dewantara telah menandingi sistem pendidikan kolonial yang sifatnya intelektualitas semata-dengan mengembangkan pendidikan berbasis budaya seperti kemanusiaan, jiwa merdeka, menghormati orangtua, sopan santun, etika, semangat kebangsaan, dan semangat juang. Sehingga pendidikan berkembang utuh menyeluruh ${ }^{\mathrm{xxxii}}$.

Bila menggunakan analisis pandangan John Deweys, yang mempengaruhi konsep pendidikan Ki Hajar Dewantara adalah filsofis pendidikan yang bersifat pragmatis. Ki Hajar mengatakan bahwa tanaman yang dipupuk itu adalah tanaman yang hidup, tidak untuk tanaman yang mati. Maknanya bahwa pendidikan harus ditujukan menurut minat dan bakat siswa saja, untuk pelajaran yang sesuai dengan minat dan bakat siswa, jangan terlalu dipaksakan. Ajari mereka sesuai dengan minat dan bakatnya. ${ }^{\text {xxiii }}$ Siswa harus memiliki jiwa merdeka, dalam arti merdeka lahir, batin serta tenaganya. Jiwa merdeka ini sangat diperlukan sepanjang jaman agar bangsa Indonesia tidak didikte negara lain. Sistem among melarang adanya hukuman dan paksaan kepada anak didik karena akan mematikan jiwa merdekanya, mematikan kreativitasnya. ${ }^{\text {xxiv }}$

Konsep jiwa merdeka ini selaras dengan filsafat progresivisme terhadap kebebasan untuk berpikir bagi anak didik, karena merupakan motor penggerak dalam usahanya untuk mengalami kemajuan secara progresif. Anak didik diberikan kebebasan berpikir guna mengembangkan bakat, kreatifitas dan kemampuan yang ada dalam dirinya agar tidak terhambat oleh orang lain. ${ }^{\mathrm{xxx}}$

Lebih lanjut Ki Hajar Dewantara dalam praktik pendidikannya di Taman Siswa membahas pendidikan sebagai sebuah proses memerdekakan. Proses memerdekakan ini dimaknai sebagai sesuatu yang eksistensial dan resistensial. Asumsi ini bukan tanpa dasar, tujuan pendidikan menurut Ki Hajar adalah alat memerdekakan siswa. ${ }^{\text {xxxvi }}$ 
Pengajaran secara umum akan berpengaruh untuk memerdekan kehidupan manusia pada aspek lahiriah. Sedangkan kemerdekaan hidup batinnya itu terdapat pada pendidikan. manusia merdeka adalah manusia yang hidupnya secara lahir dan batin tidak bergantung pada orang lain. Tetapi ia bersandar pada kekuataan sendiri (kemandirian). Adapun yang dimaksud pengajaran dan pendidikan yang berguna untuk kehidupan Bersama adalah fungsi untuk memerdekakan manusia sebagai anggota dari persatuan (rakyat). ${ }^{\text {xxvii }}$

Maka melihat pandangan Ki Hajar Dewantara, solusi untuk problem pendidikan sekarang dan visi kedepan adalah mengembangkan konsep pendidikan kemerdekaan bagi siswa yang menggabungkan pengembangan cipta, rasa, dan karsa. Sekaligus mengkontruksi semangat nasionalisme dalam dunia pendidikan. Dalam kemerdekaan pendidikan, siswa di sini diperlakukan sebagai subyek dengan tujuan untuk membangun kesadaran kritis sehingga mencapai derajat manusia merdeka, yang terwujud dengan mandiri dan dapat mengatur dirinya sendiri. ${ }^{\text {xxxviii }}$

Inti dari pemikiran KI Hajar Dewantara adalah menjadikan anak didik menjadi manusia merdeka baik dalam pikiran, hati, dan fisiknya. Dari kemerdekaan dirinya yang mampu mandiri tidak tergantung pada orang lain tersebut sebagai olah hasil daya kritisnya akan melahirkan sikap kepekaan sosial kepada sesame. Inilah yang dikenal dengan semangat humanis. Belajar dan berpendidikan hakikatnya bukan sekedar transfer ilmu pengetahuan, tetapi lebih jauh dari itu adalah membangun kesadaran kritis, bukan sekedar kesadaran naif (palsu), seperti dalam teori yang ungkapkan Paulo Freire.

Pendidikan bukan untuk menghasilkan manusia peserta didik yang memiliki kemampuan menghafal ilmu (knowledge), tanpa mengenal hakikat tujuan pendidikan. Karena kalau demikian hanya akan melahirkan murid yang pragmatis. Lembaga pendidikan hanya akan melahirkan sekedar legitimasi untuk meraih ijazah. Dan ini justru akan mengancam hakikat tujuan pendidikan itu sendiri, bahkan menjadi ancaman semakin menimba ilmu justru semakin jauh dari sikap yang menunjukan nilai-nilai manusiawi (humanis). Karena bukanlah fitrah diri kemanusiaan yang jadi tujuannya, pendidikan sudah berubah orientasi material semata; sebagai legistimasi kebangga diri (popularitas) dan gaya hidup saja.

\section{c. Pemikiran Pendidikan Paulo Freire}

Paulo Freire lahir di kota Recife, Brazil tahun 1921. Ayahnya Joqium Temistockles Freire, polisi militer yang tidak terlalu tata pada agama. Sedangkan ibunya, Edeltrus Neves Freire, beragama Katolik. Keduanya memiliki budi pekerti yang baik dan peduli pada sesama. Orangtuanya yang mengajarkan hidup adil dan peduli pada sesama dengan penuh cinta. ${ }^{\text {xxix }}$

Paulo Freire adalah seorang tokoh dari Brazil yang memperjuangkan pendidikan demi sebuah harapan yang menurut orang lain utopis, Pendidikan adalah hal yang sangat penting dalam kehidupan manusia terutama untuk 
mengenal eksistensinya. Pendidikan humanis adalah yang diperlukan masyarakat saat itu, pendidikan yang menempatkan manusia sebagai salah satu objek terpenting dalam pendidikan.

Pendidikan yang digagas oleh Paulo Freire adalah sebuah pendidikan yang membebaskan, karena saat kita mengharapkan pendidikan yang humanis, itu artinya kita sedang berjuang melawan pendidikan yang dehumanis yaitu pendidikan yang menjadikan guru sebagai pemeran utama dan murid harus menerima apapun yang disampaikan oleh gurunya, siswa tidak diberikan ruang gerak yang bebas sehingga yang dicetak bukanlah siswa yang kritis, namun siswa yang seperti robot. Paulo Freire menyebut pendidikan seperti ini sebagai "pendidikan sistem bank", dimana guru sebagai nasabah yang akan mengisi, dan siswa adalah rekening kosong yang siap di isi. ${ }^{\mathrm{xl}}$ Bagi Paulo Freire, pendidikan harus melibatkan tiga unsur sekaligus dalam suatu hubungan dialektis, yaitu "guru-yang-murid", "murid-yang-guru” dan realitas dunia. Yang pertama dan kedua merupakan subyek yang sadar. Sedangkan yang ketiga adlah obyek yang disadari. Bentuk hubungan dialektis inilah, yang tidak terlihat dalam pendidkan Gaya Bank. Maka pendidkan Gaya Bank tidak ubahnya seperti pengisian deposito. Dalam peristiwa ini ditunjukan oleh Freire, bertemulah keadaankeadaan yaitu tahu dan tidak tahu, meiliki dan tidak memiliki (pengetahuan), kepenuhan dan kekosongan, kekusaan dan pihak tanpa kekuasaan. ${ }^{\text {li }}$ Banyak teolog yang saat itu semakin terlibat secara nyata dengan kaum tertindas melalui khotbah tentang teologi politik pembebasan, dan bukan teologi politik moderinisasi pembangunan." ${ }^{\text {xlii }}$

Paulo Freire menyatakan segala bentuk penindasan di dunia ini harus dihapuskan. Kemudian ia menggagas solusinya dengan melalui jalur pendidikan yang membebaskan. Pendidikan yang saat itu menggunakan cara lama dimana belajar mengajar terlalu didominasi guru, sementara siswa hanya diberi ruang sedikit bahkan tidak diberi ruang untuk berpikir kritis. Kondisi ini yang diperjuangkan Freire untuk diubah untuk meraih pendidikan yang humanis yang akan berlangsung pada perubahan masyarakat. Diawali dengan pola pendidikan humanis dimana guru-murid berlaku sebagai subyek-subyek akan melahirkan perubahan sosial yang manusiawi.

Kesadaran kritis akan jati dirinya sebagai manusia dengan realitas sosialnya itulah konsep pembebasan menuju kemanusian yang sejati. Kesadaran yang akan melahirkan kepedulian sosial, solidaritas kepada sesame manusia itulah proses pendidikan humanis. Sehingga siswa didik setelah menimba pendidikan akan melahirkan sosok yang berkarakter peduli kepada kemanusiaan. konsientisasi, dimna setiap individu mampu melihat sistem sosial secara kritis.

Pendidikan menjadi jalan menuju peningkatan kualitas intelektual dan potensi manusia dalam mengembangkan daya kreasi dan potensi yang berbedabeda, dengan cara mengutamakan dialog antara pendidik dan peserta didik agar tercipta sebuah interaksi yang dialektis antara keduanya. Dengan aktip terlibat langsung dengan permasalahan yang nyata dan dialogis, maka pendidikan 
humanis akan menumbuhkan kesadaran yang menjauhkan seseorang dari "rasa takut". Inilah langkah awal untuk menentukan dalam upaya pendidikan yakni penyadaran (konsientisasi) dalam istilah Paulo Freire. xliii $^{\text {up }}$

Paulo Freie membagi masyarakat dalam tiga kelompok berdasarkan "kesadaran" nya, pertama, berkesadaran Magis, masyarakat yang tidak mampu melihat kaitan antara satu faktor pendidikan sebagai paradigma pembebasan lainya. Kesadaran magis lebih melihat faktor di luar manusia (natural maupun supranatural) sebagai penyebab dan ketidakberdayaan. Kedua, Kesadaran Naif. Mereka yang melihat dan memahami penyebab kekacauan dalam kehidupannya, namun mereka belum memiliki kesadaran untuk bangkit dan menggugat dan berusaha memperjuangkan apa yang harusnya mereka miliki. Ketiga, Kesadaran Kritis, merupakan kesadaran tertinggi yang mampu melihat aspek dan struktur sebagai sumber masalah. Untuk selanjutnya secara kritis menyadari struktur dan sistem sosial, politik, ekonomi, budaya dan akibatnya pada keadaan masyarakat. Adapun pendidikan dengan kesadaran kritis yang ingin diserukan oleh Freire adalah pendidikan kritis yang mendidik manusia untuk peka terhadap realita sosial. ${ }^{\text {xliv }}$

Paulo Freire memperjuangkan pendidikan yang membangkitkan kesadaran kritis (kosientisasi) sebagai awal proses humanisasi, dimana pendidikan harus dijalankan dengan kemurahan hati, kedermawanan humanis dengan menampilkan sikap manusiawi. Manusia pada dasarnya adalah merdeka (bebas). Maka humanisasi merupakan proses pembebasan manusia dari kondisi yang membuatnya tertindas (tidak merdeka) di luar kehendaknya. ${ }^{\text {xlv }}$ Dalam pandangan Paulo Freire, manusia adlaah penguasa atas dirinya, karena itu manusia itu fitrahnya merdeka (bebas). Maka humanisasi bermakna pemerdekaan atau pembebasan manusia dari kondisi yang menindas di luar dirinya. ${ }^{\text {xlvi }}$ Dalam pendidikan, menempatkan guru dan murid dalam posisi belajar Bersama. Masing-masing mereka memiliki peran sebagai subyek-subyek, bukan subyekobyek. Dalam hal ini tampak posisi guru-murid dan sebaliknya murid-guru keduanya saling berinteraksi dalam hubungan horizontal dalam konteks transformasi ilmu pengetahuan.

Dalam pandangan Paulo Freire, guru berada pada posisi guru yang demokratis yang memberikan kepercayaan kepada siswanya sebagai makhluk yang tidak hanya mampu mendiskusikan masalah, tetapi juga mampu mengatasi masalah. Dalam proses belajar-mengajar hendaknya ada hubungan dialog antara siswa dengan guru, dan kontradiksi antara keduanya harus dihapuskan supaya pendidikan menjadi benar. Guru dalam hal ini belajar melalui dialog dengan murid. Di sini guru berfungsi sebagai fasilitator bagi murid dalam proses pendidikan. ${ }^{\text {llvii }}$ Guru menjadi rekan bagi murid pada saat berhubungan dengan mereka, sebagai proses mewujudkan supaya murid muncul daya kritis menuju ke arah humanisasi. Guru berperan sebagai fasilitator, dinamisator, dan motivator bagi murid-muridnya. ${ }^{\text {xlviii }}$ 
Murid atau peserta didik adalah makhluk yang bebas memiliki alamnya sendiri. Dia bukanlah robot yang diperlakukan sebagai mainan secara manipulative. Peserta didik memiliki masa depan yang masing-masing mereka punya peran sendiri untuk menentukan nasib masa depannya. Guru sebagai pendidik berperan mengarahkan mereka sesuai minat dan bakat yang dimilikinya. Murid memiliki kebebasan untuk mewujudkan eksistensi dirinya secar terbuka dan mandiri sesuai potensi bakatnya. ${ }^{\text {xlix }}$

Belajar dalam pandangan Paulo Freire merupakan proses yang berat dalam tahapan membangun kesadaran kritis, dimana awalnya sebagaimana masyarakat umum, murid berada dalam tahap kesadaran magis (1) menuju tahap kesadaran naif (palsu) (2), kepada kesadaran kritis (kesadaran sejati) (3). Kesadaran kritis tersebut menurut Paulo Freire tidak dapat dibangun dalam pendidikan yang sistemnya seperti gaya Bank.

Dalam hal metode, pendidikan menurut Paulo Freire seharusnya tidak seperti gaya Bank; semestinya pendidikan lama yang gaya Bank tersebut yaitu guru sebagai subyek yang memiliki pengetahuan untuk diisikan kepada muridnya. ${ }^{\text {li }}$ Tetapi metode yang tepat dalam pendidikan adalah dengan dialogis, sehingga dengan demikian tidak ada salahsatu pihak yang dikorbankan. Peran dialog dalam pendidikan menunjukan bahwa pendidikan yang ideal itu bertumpu pada pendekatan kultural, bukan structural.

\section{d. Kesamaan dan Perbedaan Pandangan Ketiga Tokoh}

KH Ahmad Dahlan memiliki beberapa persamaan dengan pemikiran pendidikan Ki Hajar Dewantara, meskipun keduanya berada dalam selisih waktu yang cukup jauh. KH Ahmad Dahlan tahun 1890 sudah merintis pendidikan yang bersifat kritik sosial, rasional, modern mendobrak budaya feodalistik yang "dipelihara" kolonial Belanda. Membuka pendidikan modern dan terbuka memadukan pelajaran agama dengan modern (barat). Ketika KH Ahmad Dahlan wafat Februari 1923, Ki Hajar belum setahun mencetuskan Sekolah Tamansiswa dengan trilogy semboyan pendidikannya (1922), yang berpijak pada budaya lokal.

Keduanya memiliki kesamaan bahwa:

1) pendidikan itu harus humanis, membentuk kepribadian yang berbudi pekerti (etika) atau berakhlak mulia, dan percaya diri. Persamaan keduanya pendidikan itu harus menempatkan manusia pada jati dirinya sejati, memanusiakan manusia.

2) Pendidikan karakter yang mengedepankan prinsip keteladanan dan pentingnya membangun kesadaran dengan pendekatan dialogis; menghindari pendidikan yang indoktrinasi.

3) Pendidikan karakter yang dibangun harus sampai pada tarap implementasi atau pengamalan.

Begitu pun antara KH Ahmad Dahlan dengan Paulo Freire yang sangat jauh terpaut jarak dan waktu, tetapi pada aspek tertentu memiliki kesamaan prinsip. 
Ketika KH Ahmad Dahlan wafat di Jogyakarta tahun 1923, Paulo Freire baru berusia 2 tahun.

Adapun kesamaan pemikiran pendidikan KH Ahmad Dahlan dengan Paulo Freire, adalah:

Pendidikan yang membebaskan. KH Ahmad Dahlan memelopori pendidikan yang mengajarkan sikap kritis (membebaskan murid-muridnya dari sifat indoktrinasi dan kefeodalan dalam tradisi umat Islam dan budaya Jawa). KH Ahmad Dahlan memeolpori aksi gerakan sosial yang kemudian berkembang luas menjadi amal usaha sosial Panti Asuhan Yatim, dan rintisan Penolong Kesengsaraan Oemoem (PKO) serta klinik sebagai cikal bakal rumah sakit Muhammadiyah. Dalam hal ini, pendidikan humanis KH Ahmad Dahlan memiliki irisan kesamaan dengan telogi pembebasan (liberated humanity) seperti yang dirumuskan Paulo Freire, setengah abad setelahnya. Dimana Paulo Freire di negerinya mendorong pendidikan yang membangun kesadaran kritis.

Pendidikan yang demokratis. KH Ahmad Dahlan memberikan contoh guru yang mendatangi murid, mengubah tradisi sebelumnya dimana murid yang mendatangi guru. Ini mengajarkan kesetaraan posisi guru-murid, dan sekaligus memberi contoh dialog guru-murid sekaligus. Begitu pun Paulo Freire, menempatkan guru-murid dalam posisi sejajar sebagai sama-sama subyek dalam pendidikan.

Pendidikan yang membawa perubahan sosial masyarakat. KH Ahmad Dahlan telah memelopori perubahan sosial masyarakat dengan membuka kesadaran kritis dan rasional sekaligus memberikan solusi. Demikian pula Paulo Freire, pendidikan yang mendorong pengintegrasian realitas dan mendorong adanya agen perubahan sosial yang membebaskan dari penindasan.

Adapun kesamaan pemikiran pendidikan dari ketiga tokoh antara $\mathrm{KH}$ Ahmad Dahlan, Ki Hajar Dewantara dan Paulo Freire dapat dilihat di bawah ini:

Persamaan Pemikiran Pendidikan

KH Ahmad Dahlan-Ki Hajar Dewantara- Paulo Freire

\begin{tabular}{|c|c|c|c|c|}
\hline No & $\begin{array}{l}\text { Aspek } \\
\text { Persamaan }\end{array}$ & KH Ahmad Dahlan & $\begin{array}{ll}\text { Ki } & \text { Hajar } \\
\text { Dewantara } & \\
\end{array}$ & Paulo Freire \\
\hline 1 & $\begin{array}{l}\text { Latarbelakang } \\
\text { rumusan } \\
\text { pendidikan }\end{array}$ & $\begin{array}{l}\text { Aktivitas pendidikan } \\
\text { berangkat dari } \\
\text { keprihatinan terhadap } \\
\text { kondisi sosial } \\
\text { masyarakat saat itu } \\
\text { yang feodalistik dan } \\
\text { dibiarkan pemerintah } \\
\text { colonial, bahkan } \\
\text { tertindas } \\
\text { kolonial }\end{array}$ & $\begin{array}{l}\text { Aktivitas } \\
\text { pendidikan } \\
\text { berangkat dari } \\
\text { keprihatinan } \\
\text { terhadap kondisi } \\
\text { sosial masyarakat } \\
\text { saat itu yang } \\
\text { feodalistik dan } \\
\text { dibiarkan } \\
\text { pemerintah colonial, } \\
\text { bahkan tertindas } \\
\text { oleh colonial }\end{array}$ & $\begin{array}{l}\text { Memberantas buta } \\
\text { huruf penduduk } \\
\text { Brazil, kondisi } \\
\text { masyarakatnya yang } \\
\text { tertinggal melek } \\
\text { baca }\end{array}$ \\
\hline 2 & Implementasi & Pendidikan & Pendidikan & Pendidikan \\
\hline
\end{tabular}




\begin{tabular}{|c|c|c|c|c|}
\hline No & $\begin{array}{l}\text { Aspek } \\
\text { Persamaan }\end{array}$ & KH Ahmad Dahlan & $\begin{array}{ll}\text { Ki } & \text { Hajar } \\
\text { Dewantara } & \end{array}$ & Paulo Freire \\
\hline & Pendidikan & $\begin{array}{l}\text { dikehendakinya bisa } \\
\text { diaplikasikan dalam } \\
\text { kehidupan praktis, } \\
\text { sehingga masyarakat } \\
\text { yang berakhlak } \\
\text { mulia, cerdas, } \\
\text { rasional dan bebas } \\
\text { dari hegemoni } \\
\text { system colonial, } \\
\text { tetapi tampil modern. }\end{array}$ & $\begin{array}{l}\text { dikehendakinya bisa } \\
\text { diaplikasikan dalam } \\
\text { kehidupan praktis, } \\
\text { masyarakat yang } \\
\text { cerdas berkarakter, } \\
\text { berbudi pekerti dan } \\
\text { cinta tanah air, } \\
\text { merdeka mandiri } \\
\text { bebas dari kolonial }\end{array}$ & $\begin{array}{l}\text { mengintegrasikan } \\
\text { realitas sosial dan } \\
\text { menjadi agen untuk } \\
\text { perubahan sosial } \\
\text { masyarakat yang } \\
\text { tanpa penindasan }\end{array}$ \\
\hline 3 & $\begin{array}{l}\text { Metode } \\
\text { Pendidikan }\end{array}$ & 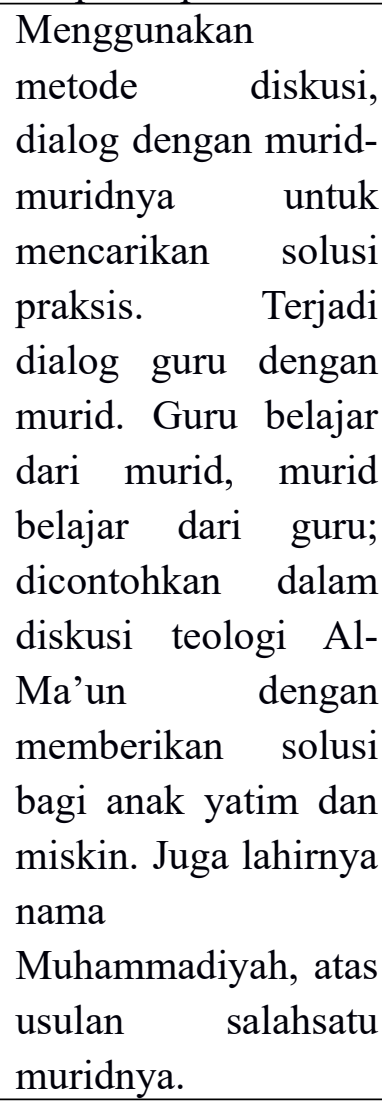 & $\begin{array}{l}\text { Menggunakan } \\
\text { metode among } \\
\text { (mengayomi) dalam } \\
3 \text { kondisi: (1) guru } \\
\text { memberi contoh } \\
\text { baik bagi murid, di } \\
\text { depan jadi teladan } \\
\text { (Ing Ngarso sung } \\
\text { tulodo), (2) di } \\
\text { tengah bareng } \\
\text { memberi semangat } \\
\text { (Ing madyo mangun } \\
\text { karso), (3) di } \\
\text { belakang } \\
\text { mendorong/ } \\
\text { mengarahkan } \\
\text { dengan memotivasi } \\
\text { (Tut wari } \\
\text { handayani) }\end{array}$ & $\begin{array}{l}\text { Pendidikan dengan } \\
\text { kesetaraan guru } \\
\text { murid, yang } \\
\text { demokratis } \\
\text { memungkinkan } \\
\text { terjadinya dialog } \\
\text { diantara mereka. } \\
\text { Guru belajar dari } \\
\text { murid, murid belajar } \\
\text { dari guru. }\end{array}$ \\
\hline
\end{tabular}

\section{SIMPULAN}

Ketiga tokoh KH Ahmad Dahlan, Ki Hajar Dewantara, dan Paulo Freire memiliki kesamaan latarbelakang secara substantive, yaitu menghadapi kondisi sosial masyarakat yang ada dalam kondisi feodal dan tertindas oleh kepentingan colonial (penjajahan).

Dalam konsep dan implementasi pendidikan ketiganya pun memiliki persamaan yaitu membangkitkan kesadaran pendidikan yang humanis (membangun nilai-nilai semangat kemanusiaan). Pendidikan yang baik adalah yang membangun kemanusiaan sejati, yang bebas mandiri dan merdeka dari tekanan indoktrinasi. 
Pada aspek metode pendidikan, mereka sama-sama memiliki pandangan yang ideal. Dalam pandangan mereka, metode pendidikan yang ideal adalah pendidikan yang menciptakan sikap demokratis, kesetaraan kedudukan antara guru dengan murid sebagai sama-sama subyek. Kedudukan mereka sebagai mitra atau partner dalam pendidikan yang saling belajar, guru belajar dari murid dan murid pun belajar dari guru. Itulah sebabnya metode yang digunakan adalah pendekatan dialogis antara guru dengan murid.

\section{ENDNOTES}


i (https://www.pikiran-rakyat.com, diakses 29 September 2020, jam 13.00.

ii (https://www.m.medicom.id diakses tanggal 29 September 2020 jam 13.00.

iii (https://www.m.medicom.iddiakses tanggal 29 September 2020 jam 13.00.

iv Yakob Godlif Malatuny, Pemikiran Tokoh-Tokoh Pendidikan Indonesia, Kontribusi Serta Implikasi Dalam Pendidikan; Jurnal Pedagogika dan Dinamika Pendidikan. Vol. 4, No. 1, April 2016: 70, dalam https://www.godliefmalatuny.blogspot.com diakses $29 \quad$ Agustus 2020

viii Doni Koesoema A, Pendidikan Karakter, Jakarta: Grasindo, 2007: 63)

ix Lihat Kamus Besar Bahasa Indonesia (KBBI) web.id, Diakses tanggal 30 Agustus 2020; https://id.m.Wikipedia.org.diakses tgl 30 Agustus 2020 ;Soedjatmoko, Humanitarianisme Soedjatmoko Visi Kemanusiaan Kontemporer, Yogyakarta: Pilar Humanika, 2005: 98, dalam Muhammad Najib Al Faruq, Pendidikan Humanisme (Komparasi Pemikiran KH Ahmad Dahlan dan Paulo Freire), Tajdida Jurnal, Vol.12, No.2, Desember 2014, hlm.165.

x Antonio Gramci, Negara dan Hegemoni, Yogyakarta: Pustaka Pelajar, 2010: 19, dalam https://scribd.com diakses tanggal 27 Agustus 2020.

xi Ali Syariati, Humanisme Antara Islam dan Mazhab Barat, Jakarta: Pustaka Hidayah, 1992: 39 dalam https://scribd.com diakses tanggal 27 Agustus 2020.

xii Antonio Gramci, Negara dan Hegemoni, Yogyakarta: Pustaka Pelajar, 2010: 19, dalam https://scribd.com diakses tanggal 27 Agustus 2020.

xiii Achmad Jainuri, Ideologi Kaum Reformis: Melacak Pandangan Keagamaan Muhammadiyah Periode Awal, (Surabaya: LPAM, 2002:193-194).

xiv Syarifuddin Jurdi (ed.), 1 Abad Muhammadiyah: Gagasan Pembaruan Sosial Keagamaan, (Jakarta: Kompas, 2010: 59);Kyai Syuja', Islam Berkemajuan: Kisah Perjuangan KH Ahmad Dahlan dan Muhammadiyah Masa Awal, (Jakarta: Al-Wasath, 2009: 62-63;180); Hilman Latief, Melayani Umat: Filantrofi Islam dan Ideologi Kesejahteraan Kaum Modernis, (Yogyakarta; Suara Muhammadiyah, 2017: 216.

xv RH Hadjid, 17 Kelompok Ayat-Ayat al-Qur'an, hal.36, dalam Achmad Jainuri, Ideologi Kaum Reformis: Melacak Pandangan Keagamaan Muhammadiyah Periode Awal, (Surabaya: LPAM, 2002: 185).

xvi Kiai Haji Ahmad Dahlan, (Jakarta: Depdikbud, 1985: 90).

xvii Lihat Hanung Bramantyo, film "Sang Pencerah" (DVD), edisi 18 Nopember 2010.

xviii Defti Arlen, Sudjarwo, Risma Margaretha Sinaga, Thought KH Ahmad Dahlan in The Field of Social And Educationall, artikel (t.t.): hlm. 11.

xix Kiai Haji Ahmad Dahlan, (Jakarta: Depdikbud, 1985: 132-133); Noor Amirudin, Humanism Education of Kiyai Haji Ahmad Dahlan (Tracing the Early Muhammadiyah Period of Education and Its Implications); Journal of Social Science Studies ISSN 2329-9150 2018, Vol. 5, No. 2, halaman,177.

xx Muhammad Najib Al Faruq, Pendidikan Humanisme (Komparasi Pemikiran KH Ahmad Dahlan dan Paulo Freire), Tajdida Jurnal, Vol.12, No.2, Desember 2014: 170

xxi Lihat Hanung Bramantyo, film “Sang Pencerah" (DVD), edisi 18 Nopember 2010; Achmad Jainuri, Ideologi Kaum Reformis: Melacak Pandangan Keagamaan Muhammadiyah Periode Awal, (Surabaya: LPAM, 2002: 160; Muhammad Najib Al Faruq, Pendidikan Humanisme (Komparasi Pemikiran KH Ahmad Dahlan dan Paulo Freire), Tajdida Jurnal, Vol.12, No.2, Desember 2014: 170

xxii https://www.republika.co.id diakses tanggal 30 Agustus 2020

xxiii https://www.kompas.com diakses tanggal 30 Agustus 2020 
xxiv https://www.biografiku.com diakses tanggal 30 Agustus 2020

xxv H.A.R. Tilaar," Sowing The Seed of Freedom: Ki Hajar Dewantara as A Pioneer of Critical Pedagogy," dalam Fattah Amal Iko Rusmana, Memerdekaan Siswa Melalui Pendidikan: Relevansi Konsepsi Pemikiran Pendidikan Ki Hajar Dewantara, artikel UNJ, hal.5 lihat pula https://www.unjkita.com dan https://www.amarsuteja.blogspot.com diakses tanggal 28 Agustus 2020.

xxvi Yakob Godlif Malatuny, Pemikiran Tokoh-Tokoh Pendidikan Indonesia, Kontribusi Serta Implikasi Dalam Pendidikan; Jurnal Pedagogika dan Dinamika Pendidikan. Vol. 4, No. 1, April 2016: 70, dalam https://www.godliefmalatuny.blogspot.com diakses 29 Agustus 2020.

xxvii Faisal Faliyandra, Model Komunikasi Pendidikan di Sosial Media pada era Perkembangan Teknologi (Kajian Pendidikan Ki Hajar Dewantara), Jurnal Islam Universalia, Vol.1 No.3 Januari 2020, hlm. 439. xxviii Faisal Faliyandra, Model Komunikasi Pendidikan di Sosial Media pada era Perkembangan Teknologi (Kajian Pendidikan Ki Hajar Dewantara), Jurnal Islam Universalia, Vol.1 No.3 Januari 2020, hlm 440-441).

xxix Faisal Faliyandra, Model Komunikasi Pendidikan di Sosial Media pada era Perkembangan Teknologi (Kajian Pendidikan Ki Hajar Dewantara), Jurnal Islam Universalia, Vol.1 No.3 Januari 2020, hlm.448.

xxx Faisal Faliyandra, Model Komunikasi Pendidikan di Sosial Media pada era Perkembangan Teknologi (Kajian Pendidikan Ki Hajar Dewantara), Jurnal Islam Universalia, Vol.1 No.3 Januari 2020, hlm. 449).

xxxi Dyah, Kajian Konsep Pendidikan Karakter Menurut KH Ahmad Dahlan dan Ki Hajar Dewantara, Proseding, Konaspi VII, Universitas Negeri Yogyakarta, 2012; hlm. 6.

xxxii Dyah, Kajian Konsep Pendidikan Karakter Menurut KH Ahmad Dahlan dan Ki Hajar Dewantara, Proseding, Konaspi VII, Universitas Negeri Yogyakarta, 2012; hlm. 2

xxxiii Ki Hajar Dewantara, Bagian Pertama: Pendidikan, (Yogyakarta: Majelis Luhur Taman Siswa, 1977: 52-53) dalam Fattah Amal Iko Rusmana, Memerdekaan Siswa Melalui Pendidikan: Relevansi Konsepsi Pemikiran Pendidikan Ki Hajar Dewantara, artikel UNJ, hlm.6, lihat pula https://www.unjkita.com diakses tanggal 28 Agustus 2020.

xxxiv Fattah Amal Iko Rusmana, Memerdekaan Siswa Melalui Pendidikan: Relevansi Konsepsi Pemikiran Pendidikan Ki Hajar Dewantara, artikel UNJ, hal.7; lihat pula https://www.unjkita.com diakses tanggal 28 Agustus 2020.; lihat https://www.jurnalugm.ac.id diakses tanggal 28 Agustus 2020.

xxxv Fattah Amal Iko Rusmana, Memerdekaan Siswa Melalui Pendidikan: Relevansi Konsepsi Pemikiran Pendidikan Ki Hajar Dewantara, artikel UNJ,hal.7 lihat pula https://www.unjkita.com diakses tanggal 28 Agustus 2020; lihat https://www.jurnalugm.ac.id diakses tanggal 28 Agustus 2020.

xxxvi Fattah Amal Iko Rusmana, Memerdekaan Siswa Melalui Pendidikan: Relevansi Konsepsi Pemikiran Pendidikan Ki Hajar Dewantara, artikel UNJ, hal.8. lihat pula https://www.unjkita.com diakses tanggal 28 Agustus 2020.

xxxvii Ki Hajar Dewantara, "Bagi Pertama, Pendidikan” (Yogyakarta: Majelis Luhur Taman Siswa, 1977) hlm. 5253 dalam Fattah Amal Iko Rusmana, Memerdekaan Siswa Melalui Pendidikan: Relevansi Konsepsi Pemikiran Pendidikan Ki Hajar Dewantara, artikel UNJ, hal.8. lihat pula https://www.unjkita.com diakses tanggal 28 Agustus 2020.

xxxviii Fattah Amal Iko Rusmana, Memerdekaan Siswa Melalui Pendidikan: Relevansi Konsepsi Pemikiran Pendidikan Ki Hajar Dewantara, artikel UNJ, hal. 13. lihat pula https://www.unjkita.com diakses tanggal 28 Agustus 2020.

xxxix Budhy Munawar-Rahman, Islam Pluralis: Wacana Kesetaraan Kaum Beriman, (Jakarta: Paramadina, 2001: 366.

xl Budhy Munawar-Rahman, Islam Pluralis: Wacana Kesetaraan Kaum Beriman, (Jakarta: Paramadina, 2001: 379)

xli Budhy Munawar-Rahman, Islam Pluralis: Wacana Kesetaraan Kaum Beriman, (Jakarta: Paramadina, 2001: 379) 
xlii Paulo Freire, Politik Pendidikan, (Yogyakarta: Pustaka Pelajar, 2007: 213), dalam Rijal Abdillah, Analisis Teoritis Dehumanisasi Pendidikan Paulo Freire," Jurnal Aqidah dan Filsafat Islam, Vo.2 N0.1 (2017), hal. 8.

xliii Paulo Freire, Politik Pendidikan, (Yogyakarta: Pustaka Pelajar, 2007: xvii), dalam Rijal Abdillah, “Analisis Teori Humanisasi Pendidikan Paulo Freire," dalam Jurnal Aqidah dan Fllsafat Islam, Vol2. No.1 (2017), hal.11.

xliv Rijal Abdillah, "Analisis Teori Humanisasi Pendidikan Paulo Freire," dalam Jurnal Aqidah dan Fllsafat Islam, Vol2. No.1 (2017), hal.11.

xlv Arisal Sopyan, Sani Rizki Firmansyah, Dedi Koswara, "Pemikiran Humanistik dalam Pendidikan: Perbandingn Pemikiran Paulo Freire dengan KI Hajar Dewantara," hal.69-70, dalam http://uin.sby.ac.id diakses tanggal 29 Agustus 2020.diakses tanggal 29 Agustus 2020.

xlvi Arisal Sopyan, Sani Rizki Firmansyah, Dedi Koswara, "Pemikiran Humanistik dalam Pendidikan: Perbandingn Pemikiran Paulo Freire dengan Ki Hajar Dewantara," hal.71 dalam http://uin.sby.ac.id diakses tanggal 29 Agustus 2020.., diakses tanggal 29 Agustus 2020.

xlvii Arisal Sopyan, Sani Rizki Firmansyah, Dedi Koswara, "Pemikiran Humanistik dalam Pendidikan: Perbandingn Pemikiran Paulo Freire dengan KI Hajar Dewantara," hal.72. dalam http://uin.sby.ac.id diakses tanggal 29 Agustus 2020.., diakses tanggal 29 Agustus 2020.

xlviii Arisal Sopyan, Sani Rizki Firmansyah, Dedi Koswara, "Pemikiran Humanistik dalam Pendidikan: Perbandingn Pemikiran Paulo Freire dengan KI Hajar Dewantara," hal.73. dalam http://uin.sby.ac.id diakses tanggal 29 Agustus 2020.diakses tanggal 29 Agustus 2020.

xlix Yamin, 2009, dalam Arisal Sopyan, Sani Rizki Firmansyah, Dedi Koswara, "Pemikiran Humanistik dalam Pendidikan: Perbandingn Pemikiran Paulo Freire dengan KI Hajar Dewantara," hal.73 dalam http://uin.sby.ac.id diakses tanggal 29 Agustus 2020.., diakses tanggal 29 Agustus 2020.

I Paulo Freire, Pendidikan Kaum Tertindas, (Jakarta: LP3ES, 1985: 49) dalam Budhy Munawar Rachman, Islam Pluralis: Wacana Kesetaraan Kaum Beriman, (Jakarta: Paramadian, 2001: 379-380); Arisal Sopyan, Sani Rizki Firmansyah, Dedi Koswara, "Pemikiran Humanistik dalam Pendidikan: Perbandingn Pemikiran Paulo Freire dengan KI Hajar Dewantara," hal.74 dalam http://uin.sby.ac.id diakses tanggal 29 Agustus 2020.

li Paulo Freire, Pendidikan Kaum Tertindas, (Jakarta: LP3ES, 1985: 49) dalam Budhy Munawar Rachman, Islam Pluralis: Wacana Kesetaraan Kaum Beriman, (Jakarta: Paramadina, 2001: 379-380).

Emy Susanti Hendarso, "Penelitian Kualitatif: Sebuah Pengantar," dalam Bagong Suyanto \& Sutinah, Metode Penelitian Sosial: Berbagai Pendekatan Alternatif, Jakarta: Prenada Media, 2007:168.

M. Nasir, Metodologi Penelitian, Jakarta: Eresco, 1985: 54

Steven Adam J. Moleong, Metodologi Penelitian Kualitatif, Bandung: Remaja Rosda Karya, 1999: 3.

Munzir, Metodologi Penelitian Pendidikan, Jakarta: Rajawali Press, 1999: 62

\section{DAFTAR PUSTAKA}

Achmad Jainuri, Ideologi Kaum Reformis: Melacak Pandangan Keagamaan Muhammadiyah Periode Awal, Surabaya: LPAM, 2002

Ali Syariati, Humanisme Antara Islam dan Mazhab Barat, Jakarta: Pustaka Hidayah, 1992 Antonio Gramci, Negara dan Hegemoni, Yogyakarta: Pustaka Pelajar, 2010: Bagong Suyanto \& Sutinah, Metode Penelitian Sosial: Berbagai Pendekatan Alternatif, Jakarta: Prenada Media, 2007.

Budhy Munawar-Rahman, Islam Pluralis: Wacana Kesetaraan Kaum Beriman, Jakarta: Paramadina, 2001 
Defti Arlen, Sudjarwo, Risma Margaretha Sinaga, Thought KH Ahmad Dahlan In The Field Of Social And Educational, (Artikel t.t.)

Doni Koesoema A, Pendidikan Karakter, Jakarta: Grasindo, 2007

Dyah, Kajian Konsep Pendidikan Karakter Menurut KH Ahmad Dahlan dan Ki Hajar

Dewantara, Proseding, Konaspi VII, Universitas Negeri Yogyakarta, 2012

Fattah Amal Iko Rusmana, "Memerdekaan Siswa Melalui Pendidikan: Relevansi Konsepsi

Pemikiran Pendidikan Ki Hajar Dewantara," artikel UNJ,

Hanung Bramantyo, film “Sang Pencerah” (DVD), edisi 18 Nopember 2010.

Hendi Irawan Januar Barkah, K.H Ahmad Dahlan Perannya Dalam Membangun Sistem Pendidikan

Hilman Latief, Melayani Umat: Filantrofi Islam dan Ideologi Kesejahteraan Kaum Modernis, (Yogyakarta; Suara Muhammadiyah, 2017

Kyai Syuja', Islam Berkemajuan: Kisah Perjuangan KH Ahmad Dahlan dan

Muhammadiyah Masa Awal, Jakarta: Al-Wasath, 2009

M. Nasir, Metodologi Penelitian, Jakarta: Eresco, 1985: 54

Mohamad Ali, M.Pd. Pages : xxxvi + 326 pages Edition : I, October 2017 Publisher :

Suara Muhammadiyah

Muhammad Najib Al Faruq, Pendidikan Humanisme (Komparasi Pemikiran KH Ahmad

Dahlan dan Paulo Freire), Tajdida Jurnal, Vol.12, No.2, Desember 2014.

Muhammad Samsudin, Pendidikan Anak Perspektif Islam dan Barat (Studi Analisis

Pendekatan Filosofis dan Ilmu Pendidikan), Jurnal Pendidikan Universitas Garut,

Vol. $\quad$ 09, No.01, 2015, 33-58

Munzir, Metodologi Penelitian Pendidikan, Jakarta: Rajawali Press, 1999

Nur Wachid Abdul, Rizki Hikmawan, Burhanuddin, Pendidikan Berkemajuan: Telaah Konsep Pemikiran Pendidikan K.H Ahmad Dahlan, Prosiding Seminar Nasional FKIP Universitas Muhammadiyah Cirebon 2018 Cirebon, 21 April 2018 , 202

Noor Amirudin, Humanism Education of Kiyai Haji Ahmad Dahlan (Tracing the Early Muhammadiyah Period of Education and Its Implications); Journal of Social Science Studies ISSN 2329-9150 2018, Vol. 5, No. 2, halaman,177.

Steven Adam J. Moleong, Metodologi Penelitian Kualitatif, Bandung: Remaja Rosda Karya, 1999

Suswandari \& Suwarno, K.H. Ahmad Dahlan's (1869 - 1923) Thought And His Struggle For The Abolition Of Feudalism Through Reformation Of Islamic Education;

HISTORIA: International Journal of History Education, Vol. XI, No. 1 (June 2010), hlm.

Sutrisno Kutoyo, Kiai Haji Ahmad Dahlan, (Jakarta: Depdikbud, 1985: 90).

Syarifuddin Jurdi (ed.), 1 Abad Muhammadiyah: Gagasan Pembaruan Sosial Keagamaan, (Jakarta: Kompas, 2010

Antonio Gramci, Negara dan Hegemoni, Yogyakarta: Pustaka Pelajar, 2010: 19, dalam https://scribd.com diakses tanggal 27 Agustus 2020

Biografi Ki Hajar Dewantara dalam https://www.republika.co.id diakses tanggal 30 Agustus 2020

Biografi Ki Hajar Dewantara dalam https://www.kompas.com diakses tanggal 30 Agustus 2020 
Biografi Ki Hajar Dewantara dalam https://www.biografiku.com diakses tanggal 30 Agustus 2020

Fattah Amal Iko Rusmana, Memerdekaan Siswa Melalui Pendidikan: Relevansi Konsepsi Pemikiran Pendidikan Ki Hajar Dewantara, artikel UNJ, hal.7; lihat pula https://www.unjkita.com diakses tanggal 28 Agustus 2020.; lihat https://www.jurnalugm.ac.id diakses tanggal 28 Agustus 2020.

H.A.R. Tilaar," Sowing The Seed of Freedom: Ki Hajar Dewantara as A Pioneer of Critical Pedagogy," dalam Fattah Amal Iko Rusmana, Memerdekaan Siswa Melalui Pendidikan: Relevansi Konsepsi Pemikiran Pendidikan Ki Hajar Dewantara, artikel UNJ, hal.5 lihat pula https://www.unjkita.com dan https://www.amarsuteja.blogspot.com diakses tanggal 28 Agustus 2020

Humanis dalam https://www.KBBI.web.id diakses tanggal 30 Agustus 2020; https://id.m.Wikipedia.org.diakses tg1 30 Agustus 2020

Ki Hajar Dewantara, Bagian Pertama: Pendidikan, (Yogyakarta: Majelis Luhur Taman Siswa, 1977: 52-53) dalam Fattah Amal Iko Rusmana, Memerdekaan Siswa Melalui Pendidikan: Relevansi Konsepsi Pemikiran Pendidikan Ki Hajar Dewantara, artikel UNJ, hlm.6, lihat pula https://www.unjkita.com diakses tanggal 28 Agustus 2020

Ki Hajar Dewantara, "Bagi Pertama, Pendidikan" (Yogyakarta: Majelis Luhur Taman Siswa, 1977) hlm. 52-53 dalam Fattah Amal Iko Rusmana, Memerdekaan Siswa Melalui Pendidikan: Relevansi Konsepsi Pemikiran Pendidikan Ki Hajar Dewantara, artikel UNJ, hal.8. lihat pula https://www.unjkita.com diakses tanggal 28 Agustus 2020 